\title{
Evolution of the Gelasian (Pleistocene) slope turbidite systems of southern Marche (Peri- Adriatic basin, central Italy)
}

\section{Claudio Di Celma, Riccardo Teloni \& Andrea Rustichelli}

To cite this article: Claudio Di Celma, Riccardo Teloni \& Andrea Rustichelli (2016) Evolution of the Gelasian (Pleistocene) slope turbidite systems of southern Marche (Peri-Adriatic basin, central Italy), Journal of Maps, 12:1, 137-151, DOI: 10.1080/17445647.2014.995724

To link to this article: https://doi.org/10.1080/17445647.2014.995724
○
(C) 2015 Claudio Di Celma

View supplementary material $₫$

曲 Published online: 13 Jan 2015.

Submit your article to this journal

LII Article views: 303

View Crossmark data \lceil

Citing articles: 4 View citing articles $₫$ 


\title{
SCIENCE
}

\section{Evolution of the Gelasian (Pleistocene) slope turbidite systems of southern Marche (Peri-Adriatic basin, central Italy)}

\author{
Claudio Di Celma ${ }^{\mathrm{a} *}$, Riccardo Teloni ${ }^{\mathrm{b}}$ and Andrea Rustichelli ${ }^{\mathrm{a}}$ \\ ${ }^{a}$ School of Science and Technology, Geology Division, University of Camerino, Camerino, Italy; ${ }^{b}$ School \\ of Earth and Environment, University of Leeds, Leeds, UK
}

(Received 22 August 2014; resubmitted 2 December 2014; accepted 3 December 2014)

\begin{abstract}
Examples of slope channels and canyons being diverted by structurally related sea-floor topography are commonly found both on the modern seabed and in the subsurface, in deepwater fold and thrust belts but their depositional histories have rarely been documented using examples from outcrop. The synthesis of outcrop (original geological field mapping at 1:10,000 scale) and subsurface data sets from the early Pleistocene stratigraphic succession of the Peri-Adriatic basin provides a window into the overall evolutionary pattern of large intraslope turbidite systems that, during the Gelasian (2.58-1.80 Ma), shed Apenninederived clastic sediments into the adjacent deep-water basin. Trends from mapping and paleocurrent indicators converge to indicate that the sea-floor bathymetric expression of a thrust-related anticline, the north-trending Jesi-Nereto-Zaccheo structure, likely influenced the downslope transport direction of gravity flows and sediment dispersal pattern. During early and middle Gelasian time, coarse-grained turbidite deposition occurred on the western flank of the intraslope anticline by westerly sourced, northward-flowing turbidity currents, indicating that the opposing sea-floor topography was sufficient to cause the diversion of turbidite systems, forcing them to travel near parallel to the east-facing regional paleoslope for significant distances. By very late Gelasian time, the intraslope accommodation space on the western flank of the anticline had filled and turbidites were dispersed through diporiented conduits incising across the crest of the underlying structure.
\end{abstract}

Keywords: submarine slope systems; Gelasian; Peri-Adriatic basin

\section{Introduction}

Diversion in deep-water channels and canyon courses has been described from a number of modern to very young intraslope turbidite systems where preexisting or developing seabed topography associated with thrust-related folds is present (e.g. Bourget et al., 2011; Chiang \& Yu, 2006; Clark \& Cartwright, 2009; Kukowski et al., 2001; Mayall et al., 2010; Mountjoy, Barnes, \& Pettinga, 2006). Despite this, however, it would appear that published outcrop examples of channel diversion as a consequence of sea-floor topography are relatively scarce in ancient structurally complex slope systems (e.g. Cronin, 1995; Hodgson \& Haughton, 2004).

\footnotetext{
${ }^{*}$ Corresponding author. Email: claudio.dicelma@unicam.it
}

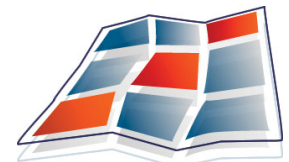




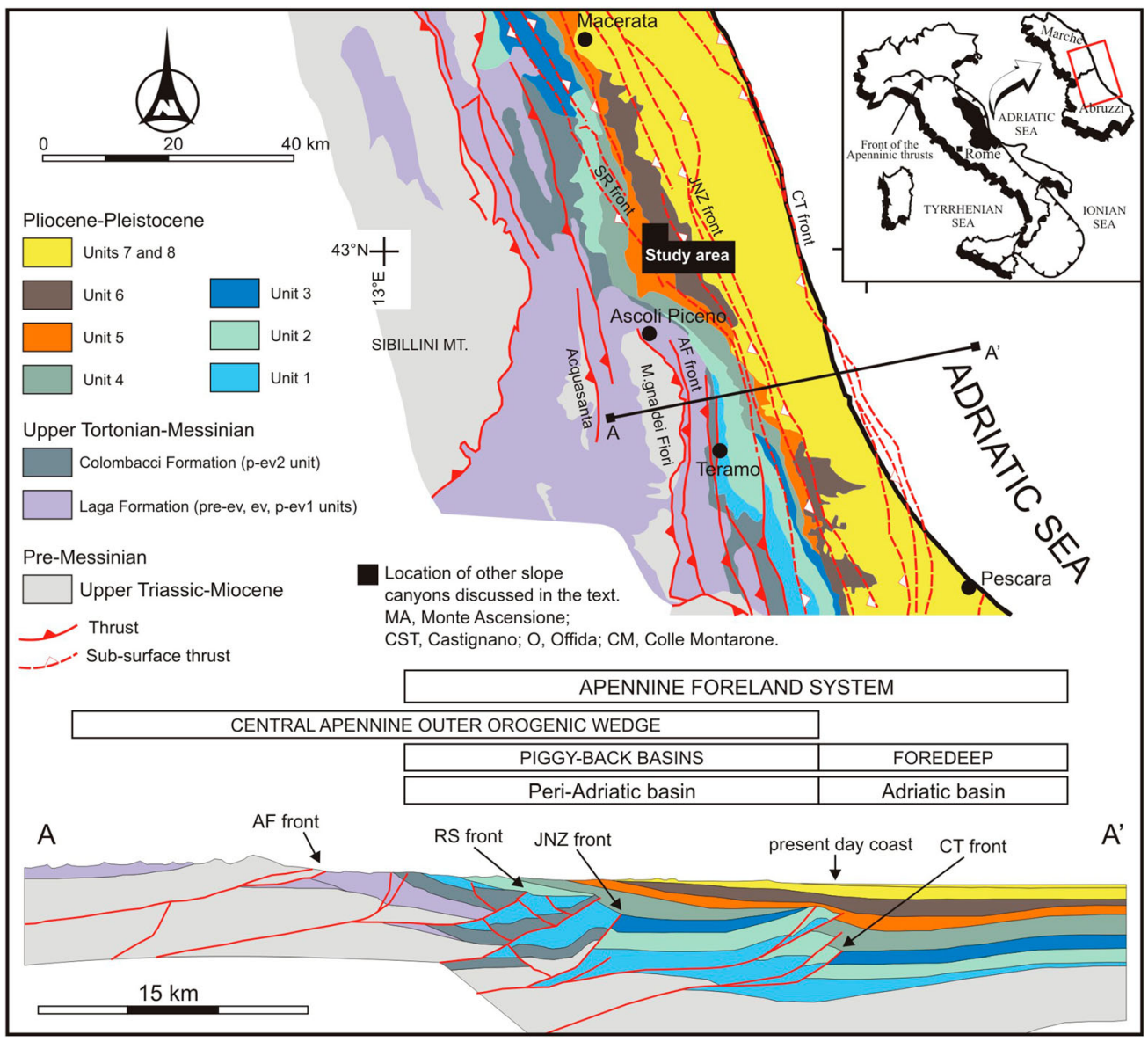

Figure 1. Generalized tectonic map of eastern central Italy, showing the location of the study area. Geological section redrawn and modified from Artoni (2013).

Regional field mapping of the exhumed early Pleistocene sedimentary succession of the PeriAdriatic basin (eastern central Italy) led to the identification of a series of deeply incised, mixed mud, and coarse-grained clastic slope turbidite systems (Di Celma, 2011; Di Celma, Cantalamessa, \& Didaskalou, 2013; Di Celma, Cantalamessa, Didaskalou, \& Lori, 2010; Di Celma, Teloni, \& Rustichelli, 2014), which preserve an extraordinary record of orbitally dictated glacio-eustatic changes in the sea level (Cantalamessa et al., 2009; Di Celma \& Cantalamessa, 2012). This article deals with four of these turbidite systems exposed at Monte Ascensione, Castignano, Offida, and Montedinove in southern Marche (Figure 1) and focuses on the exceptional opportunity they provide to document, from an outcrop perspective, the important impact of structurally generated bathymetric relief on the routing of gravity currents depositing sand on deep-water basin floors and the long-term evolution of continental slope morphology from a thrust-related stepped slope, to a smooth, healed slope.

\section{Geological and stratigraphic setting}

The Plio-Pleistocene Peri-Adriatic basin is the last of a series of foredeep basins developed from the Oligocene to the Neogene in front of the growing Apennine orogenic wedge and in relation to 
the passive westward subduction of the Adria Plate (e.g. Argnani \& Ricci Lucchi, 2001; Doglioni, 1991; Malinverno \& Ryan, 1986; Ricci Lucchi, 1986). During this time, compressional deformation migrated eastward so that the sedimentary infills of the older foredeeps were progressively incorporated into the orogenic wedge (e.g. Artoni, 2013; Bigi et al., 2013; Ori et al., 1991). Detailed reconstructions of the tectonic and stratigraphic evolution of the late Miocene-Pleistocene Central Apenninic foreland basin system in the Marche-Abruzzi sector are provided by Artoni (2013) and Bigi et al. (2013). This portion of the basin assumed its present-day configuration during the Pliocene and early Pleistocene when, as a result of the progressive eastward propagation of the thrust fronts, the previous foredeep was fragmented into discrete piggyback basins limited on both sides by northward-striking thrust fronts and related folds (Ori et al., 1991). On the whole, these structures appear to propagate in a forward-breaking sequence and, therefore, are increasingly younger from west to east. According to Artoni (2013), the sequence of structures from west to east is: the M. Acuto-Montagna dei Fiori (MAF), the Strada-Roccafinadamo (SR), the Jesi-Nereto-Zaccheo (JNZ), and the Campomare-Tortoreto (CT) thrust fronts (Figure 1). The most internal structure, the MAF thrust front, crops out in the Montagna dei Fiori anticline, to the southwest of the study area, and exposes mainly Miocene and older carbonate successions, whereas the other three are thrust-related anticlines and are subsurface structures buried, mostly, beneath Pleistocene cover (Artoni, 2013; Tozer et al., 2006). During middle Pleistocene time, this portion of the basin fill succession recorded an overall shallowing-upward trend from slope, through shelf, to coastal and alluvial deposits (Cantalamessa \& Di Celma, 2004), indicating that sediment supply exceeded the rate at which accommodation was created in the basin.

\section{Study area and methods}

The 1:20,000-scale geological map of the Gelasian (Pleistocene) slope turbidite systems and enclosing mudstones presented in this study (Main Map) encompasses an area of roughly $125 \mathrm{~km}^{2}$ in the southern part of Marche and was originally mapped at 1:10,000 scale using the topographic maps of the Regione Marche 'Carta Tecnica Regionale' (sections 314050, $326030,326040,326070,326080,327050)$. Based on a variety of characteristics, including primary sedimentary structures, bed thickness, textures, dominant grain size and internal bedding architecture, the sediments exposed in the study area have been subdivided into seven recurring facies associations (Figure 2), each of these reflecting specific gravity-induced depositional elements and slope background deposition: (i) clast-supported conglomerates (gravelly channel-fill); (ii) amalgamated sandstones (late stage sandy channel-fill); (iii) medium- to thick-bedded tabular sandstones (sandy frontal splay); (iv) thin- to thick-bedded channelized sandstones (sandy channel-fill); (v) medium- to very thin-bedded sandstones and mudstones (heterolithic levee-overbank deposits); (vi) pebbly mudstones and chaotic beds (mud-rich mass-transport deposits) and (vii) massive mudstones (slope background hemipelagic deposits). These facies associations are commonly ordered into repetitive, fining-upward stacking patterns that impart a pronounced vertical cyclicity to the turbidite systems. The descriptive facies association scheme, based on turbidite divisions from Bouma (1962) and Lowe (1982), was designed to take into account the principal sedimentological characters of the lithologies encountered in the studied succession and is summarized in Table 1. Field mapping of three-dimensional facies distributions was supplemented by line drawings over high-resolution photographic panels of inaccessible cliff faces, extensive collection of paleocurrent readings, measurement at dm-scale of vertical stratigraphic sections and a southwest-northeast-oriented seismic reflection profile (Figure 3), which provided the larger context for interpreting the overall evolution of the area. Paleocurrent trends were obtained from imbricate pebbles, channel-margin orientations, cross-beds, 

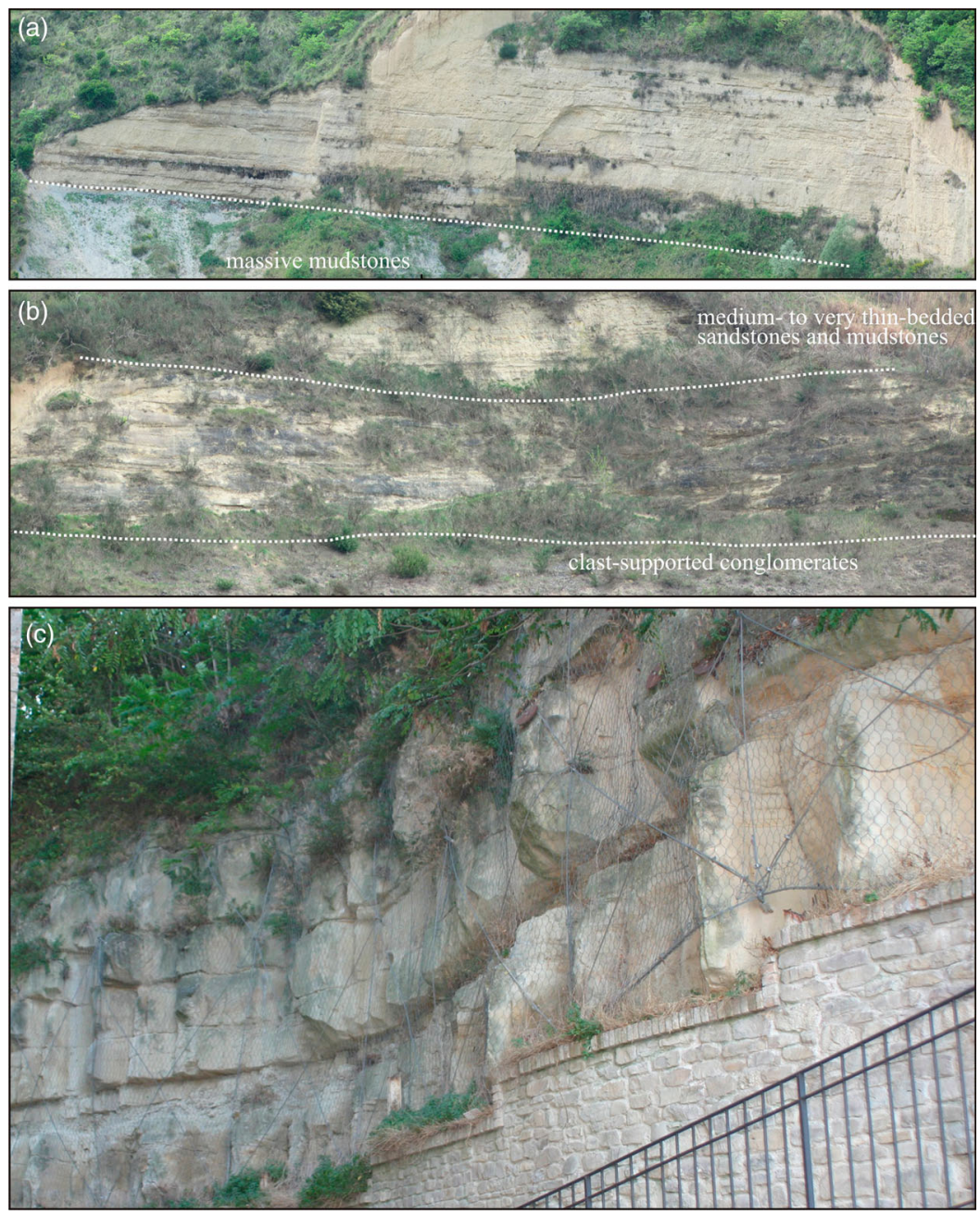

Figure 2. Compilation of field photographs showing the main facies associations observed in the four turbidite systems documented in this paper. Description and interpretation of their salient sedimentological attributes are provided in Table 1. (a) Clast-supported conglomerates (gravelly channel-fill) underlain by massive mudstones; (b) amalgamated sandstones (late stage sandy channel-fill) underlain by clast-supported conglomerates and overlain by medium- to very thin-bedded sandstones and mudstones; (c) medium- to thick-bedded tabular sandstones (sandy frontal splay); (d) thin- to thick-bedded channelized sandstones (sandy channel-fill) underlain by chaotically deformed strata including mudstone-rich debris-flow deposits. The white box is featured in Part (f); (e) medium- to very thin-bedded sandstones and mudstones (heterolithic levee-overbank deposits). Note the overall fining- and thinning-upward stratal pattern resulting from the juxtaposition of a number of discrete, metre-scale fining- and thinning-upward packets (black arrows); and (f) mud-rich mass-transport deposits including folded mudstone beds and pebbly mudstones characterized by the presence of shelf-derived exotic carbonate clasts and intraformational angular mudstone clasts. Encircled hammer for scale.

asymmetric ripple crests, sole marks, and other unidirectional indicators. Measurements taken from beds dipping more than $15^{\circ}$ were first corrected by restoration of bedding planes on a stereonet. These data were analyzed using the freeware program EZ-ROSE by Baas (2000) with rose diagrams being subdivided into $5^{\circ}$ classes. Paleocurrent maps for the studied turbidite systems were then constructed and superimposed upon the geological map. 

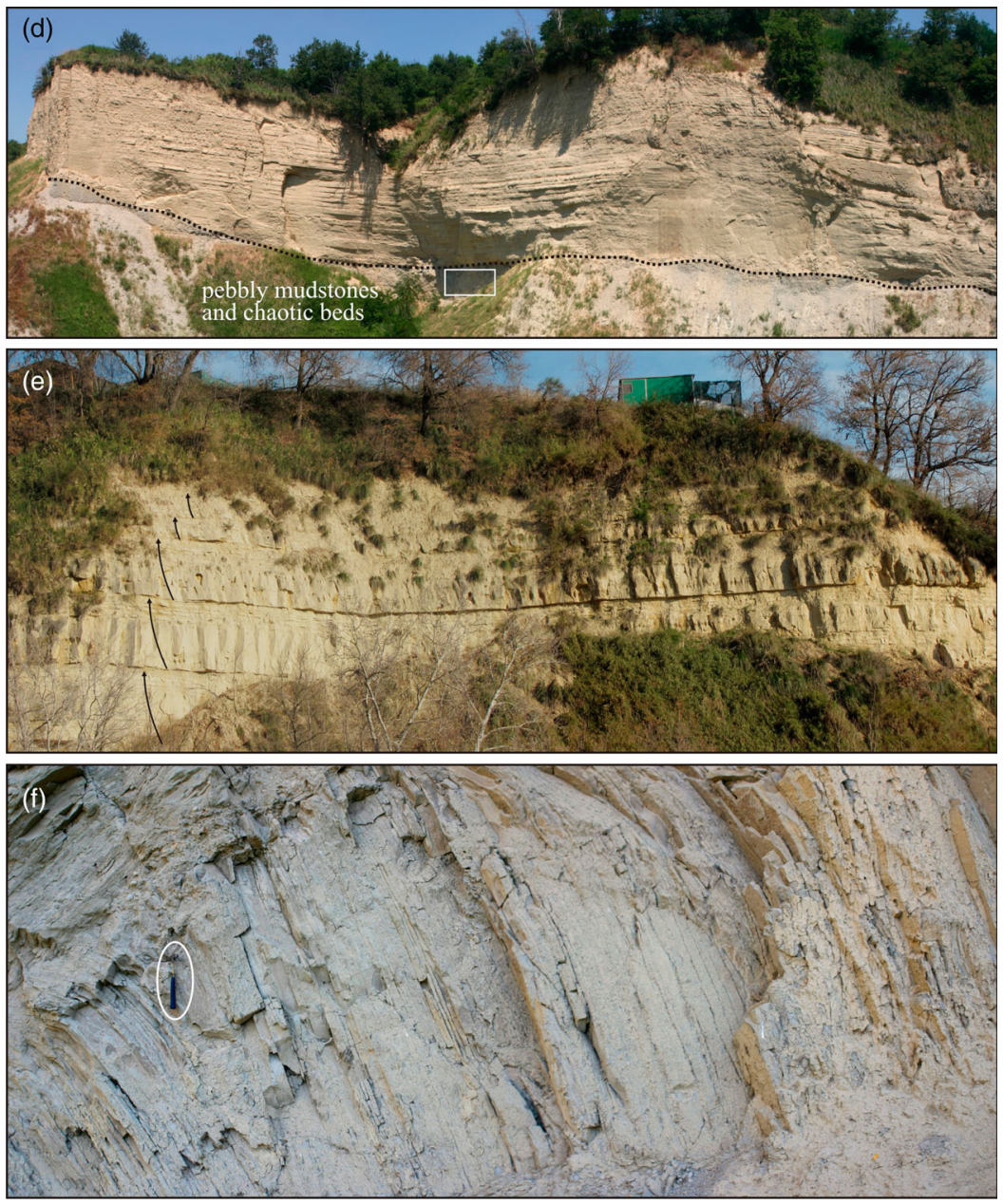

Figure 2. Continued

\section{The slope turbidite systems}

During the Gelasian, the southern Marche study area was a structurally complex, east-facing submarine slope the profile of which was affected by a north-trending thrust-related anticline known as the Jesi-Nereto-Zaccheo structure (Artoni, 2013). In this region, a series of erosively confined, sandstone- and conglomerate-filled turbidite systems (namely, Monte Ascensione, Castignano, Offida, and Montedinove systems, Figure 4) developed along the length of the slope and served as point-source conduits through which coarse sediment was transported to the deeper waters of the Peri-Adriatic basin. Microfossil assemblages indicate that sediments were deposited at upper bathyal depths, between 200 and $400 \mathrm{~m}$ (Di Celma et al., 2013). Clast composition of the turbidite sediments records extrabasinal input and includes a variety of lithologies (limestone, chert, marl, calcarenite, and sandstone) derived from erosion of Late Jurassic to Miocene formations cropping out in the adjacent central Apennine thrust belt, pointing to major source regions to the west. Analogous deep-water slope channel systems with associated gravitydriven sediment transport and depositional processes have been documented off the coast of the Abruzzi region in a 3-D seismo-stratigraphic study of the Plio-Pleistocene foredeep deposits 
Table 1. Sedimentologic attributes of lithofacies identified in the study area.

\begin{tabular}{llll}
\hline Lithology & Description & Interpretation & Depositional element
\end{tabular}

Clast-supported Poorly sorted, clast-supported, granule- to conglomerates cobble-size, medium- to thick-bedded conglomerates in a coarse sandy matrix variably interbedded with a significantly minor proportion of thin lenticular sandstone beds and pebbly mudstones. Clasts are wellrounded and extrabasinal. Internally, beds are mostly massive or with subordinate inverse grading. The prevalent bedding is tabular, lenticular or, to a lesser extent, crossstratified. Extensive channeling and scouring have produced complex cross-cutting relationships. The paleocurrent data indicate a broad dispersion about the mean direction at individual localities

Amalgamated sandstones

This lithofacies consists of fully amalgamated, medium- to coarse-grained sandstone beds ranging from less than 1 to over $3 \mathrm{~m}$ in thickness and displaying abundant basal scours. Intervening mudstone drapes are present between some sandstone beds but are not common and, where present, are generally discontinuous due to erosion. Internally, sandstone beds are typically ungraded or crudely normally graded and structureless with small pebbles or granules suspended within sandstone at their bases
Massive and normally graded conglomerate depositional units (R3) suggest that most of the clasts were deposited directly from suspension sedimentation beneath

channelized, gravelly, high-concentration turbidity currents. Sets of large-scale, crossstratified conglomerate beds (R1) indicate significant bed-load transport of gravel- and cobble-forming bars in the channels and were deposited by largely bypassing turbulent flows

(n)

\section{Conglomerate-dominated channel-}

complex: The poorly sorted but clastsupported texture of the conglomerates, their high degree of channeling, the multiple truncation surfaces, the variability, and noticeable dispersion in the prevailing

paleocurrent directions, all point to suggest that this lithofacies relates to a very active, deep-marine braid plain system characterized by a dense network of shifting, multiple-thread, relatively shortlived channels within a submarine channel belt

These fully amalgamated, ungraded, or crudely normally graded and structureless sandstone beds (S3) were deposited rapidly and represent suspension sedimentation by collapsing, highly sediment-charged turbidity flows. The paucity of overlying traction structured or fine-grained turbidite divisions in amalgamated S3 sedimentation units most probably results from either sediment bypass or subsequent erosion
Late stage channel-fill: this facies association is commonly found immediately overlying channel-fill conglomerates and appears to represent late-stage channel-fill deposited immediately before channel abandonment 
Medium- to thick-bedded amalgamated sandstones

Medium- to thick-bedded tabular sandstones
It consists of medium- to coarse-grained sandstones, and subsidiary pebbly sandstones, mudstone-clast breccia, and lenses of pebble and cobble conglomerate. Sandstone beds are medium- to thick-bedded and display abundant basal scours and amalgamation surfaces. Mudstone drapes between sandstone beds are rare to absent. Internally, sandstone sedimentation units are typically ungraded or crudely normally graded and structureless, preserving only dewatering structures. Some beds show faint to well-developed parallel lamination near the top. Lateral continuity of beds is highly variable and controlled by the presence of erosional cuts. The bedding architecture between succeeding erosional surfaces displays an overall thinning-upward trend

Laterally persistent, medium- to thick-bedded, medium- to fine-grained, massive to subtly graded sandstones. Some thicker beds are accompanied by plane-parallel laminations in the uppermost parts where convoluted laminae are occasionally present. Bottoms of sandstones contain locally abundant too marks with subordinate flute casts and load structures, whereas their tops may be even but commonly contain ripples. Individual sandstone beds are tabular and separated by thin packages of very thin-bedded siltstone and mudstone
Thick-bedded, amalgamated, massive to normally graded, sandstone beds rich in dewatering structures are commonly interpreted as the result of rapid suspension deposition by collapsing, highly sedimentparallel lamination division $(\mathrm{Tb})$ forms via repeated collapse of traction carpets at lower sediment fall out rates. The lenticular mudstone-clast breccia and pebble to cobble conglomerates are bypass lags built out of clasts left behind by through-going, highdensity gravity flows charged turbulent flows (S3). The plane-

\section{Sandstone-dominated channel complex:} Based on the complex internal organization, each of these sandstone bodies consists of the remnants of a series of erosive-based laterally stacked turbidite channel-fills (i.e. they are sand-prone channel complexes). This type of sedimentary architecture records multiple episodes of channel incision, bypass, and filling that, in turn, can be interpreted as the product of repeated cycles of increasing than decreasing flow energy

\section{These sandstones are regarded to reflect rapid} suspension sedimentation by collapsing,

highly sediment-charged turbidity currents

(S3). The plane-parallel lamination division

$(\mathrm{Tb})$ at the top of some massive or normally graded beds forms via repeated collapse of traction carpets at slightly lower suspendedload sedimentation rates. Very thin-bedded siltstone and mudstone ( $\mathrm{Td}$ and Te divisions) represent deposition from the less energetic, low-density turbidity currents
Frontal splay: The apparent absence of channelization, the overall tabular nature of the sandstone beds, characterized by the absence of intense scouring at the base and preservation of intervening mudstone intervals, and some evidence for flow collapse and mass-dumping of the highlithofacies may have been deposited by rapidly expanding flows in a relatively unconfined setting, such as at the mouth of a leveed channel as part of a frontal splay density loads of the flows suggest that this 


\begin{tabular}{|c|c|c|c|}
\hline Lithology & Description & Interpretation & Depositional element \\
\hline $\begin{array}{l}\text { Medium- to very } \\
\text { thin-bedded } \\
\text { sandstones } \\
\text { and } \\
\text { mudstones }\end{array}$ & $\begin{array}{l}\text { This facies association displays an overall } \\
\text { fining- and thinning-upward stratal pattern. } \\
\text { At the base, they may comprise tabular, } \\
\text { medium-bedded, partially amalgamated, } \\
\text { normally graded sandstone beds showing a } \\
\text { structureless division at base and planar- } \\
\text { parallel lamination at top intercalated with } \\
\text { packets of thinly interbedded ripple- } \\
\text { laminated sandstones and massive } \\
\text { mudstones. These beds are organized into } \\
\text { distinct, metre-scale, fining- and thinning- } \\
\text { upward packages, each of which contains, } \\
\text { on average, thinner- and finer-grained } \\
\text { sandstone beds than the previous one. As a } \\
\text { consequence of this vertical arrangement, } \\
\text { sandstone beds become progressively less } \\
\text { common upward, giving way to an upper } \\
\text { section dominated by thin- to very thin- } \\
\text { bedded, ripple-laminated, fine-grained } \\
\text { sandstones alternating with structureless } \\
\text { mudstone layers of similar thickness }\end{array}$ & $\begin{array}{l}\text { The thicker, structureless }(\mathrm{Ta}) \text { and planar- } \\
\text { parallel-laminated }(\mathrm{Tb}) \text { sandstone beds } \\
\text { represent deposition from high-density } \\
\text { currents. The thin- to very thin-bedded, } \\
\text { ripple-laminated }(\mathrm{Tc}) \text { sandstones alternating } \\
\text { with mudstone layers (Te) or hemipelagic } \\
\text { background sedimentation) record deposition } \\
\text { from depletive, low-concentration turbidity } \\
\text { currents }\end{array}$ & $\begin{array}{l}\text { Levee-overbank: This facies association is } \\
\text { interpreted to represent levee-overbank } \\
\text { deposits that were emplaced by } \\
\text { decelerating, moderate- to low- } \\
\text { concentration turbidity flows that spilled out } \\
\text { of nearby channels. The channel-levee } \\
\text { interpretation is consistent with sedimentary } \\
\text { processes dominated by traction, the } \\
\text { occurrence of laterally adjacent channel- } \\
\text { fills, and the well-defined fining- and } \\
\text { thinning-upward character of these } \\
\text { sediments. Within levee-overbank settings, } \\
\text { the finely laminated sandstones and } \\
\text { siltstones are interpreted to have been } \\
\text { created by pulses in the thickness and grain } \\
\text { size composition of the overspilling flows } \\
\text { that, in turn, may have been generated by } \\
\text { the presence of internal waves within the } \\
\text { turbidity currents transiting the channels }\end{array}$ \\
\hline $\begin{array}{l}\text { Pebbly } \\
\text { mudstones } \\
\text { and chaotic } \\
\text { beds }\end{array}$ & $\begin{array}{l}\text { Folded and distorted thin-bedded mudstones } \\
\text { variably interbedded with a poorly sorted } \\
\text { mixture of pebble- to cobble-size } \\
\text { extrabasinal clasts and intrabacinal angular } \\
\text { mudstone clasts set in a muddy matrix. } \\
\text { Typically the folds are tight to isoclinal and } \\
\text { may have upright axial planes }\end{array}$ & $\begin{array}{l}\text { Deposits from sediment slumps and cohesive } \\
\text { debris flows }\end{array}$ & $\begin{array}{l}\text { Mass-transport deposit: Similar chaotic } \\
\text { packages are commonly referred to as mass- } \\
\text { transport deposits or mass-transport } \\
\text { complexes. Based on the abundance of } \\
\text { well-rounded extrabasinal clasts, these } \\
\text { sediments are interpreted as resulting mostly } \\
\text { from mass wasting of the shelf-edge staging } \\
\text { area and downslope transport, with minor } \\
\text { contribution from local failure of steep } \\
\text { canyon walls }\end{array}$ \\
\hline $\begin{array}{l}\text { Massive } \\
\text { mudstones }\end{array}$ & $\begin{array}{l}\text { Pale blue-gray, massive or faintly bedded } \\
\text { mudstones rich in benthic and planktonic } \\
\text { microfauna (foraminifera and nannofossils) } \\
\text { and punctuated by rare intercalations of thin, } \\
\text { very fine-grained sandstone beds }\end{array}$ & $\begin{array}{l}\text { This lithofacies indicates slow deposition from } \\
\text { suspension fallout of hemipelagic particles } \\
\text { and unusual sedimentation events by very } \\
\text { dilute, waning, unconfined turbidity currents }\end{array}$ & Slope background hemipelagic deposition \\
\hline
\end{tabular}


of the Central Adriatic Sea (Dalla Valle et al., 2013; Tinterri \& Lipparini, 2013). Based on integrated chronostratigraphic data (Cantalamessa et al., 2009; Di Celma \& Cantalamessa, 2012), sediments of the Monte Ascensione and Castignano systems were deposited during the early and middle Gelasian age, respectively, whereas those of the Offida and Montedinove systems were roughly coeval and were deposited at the very end of the Gelasian age (Figure 5).

\subsection{Monte Ascensione system}

The Monte Ascensione succession represents the oldest turbidite system exposed in the study area (Di Celma et al., 2014). Its strata crop out over an area of approximately $40 \mathrm{~km}^{2}$ at the western end of the investigated area and extend from the Monte Ascensione to the south, where their eroded up-system extent projects into the air, and the village of Montelparo in the north. At the current

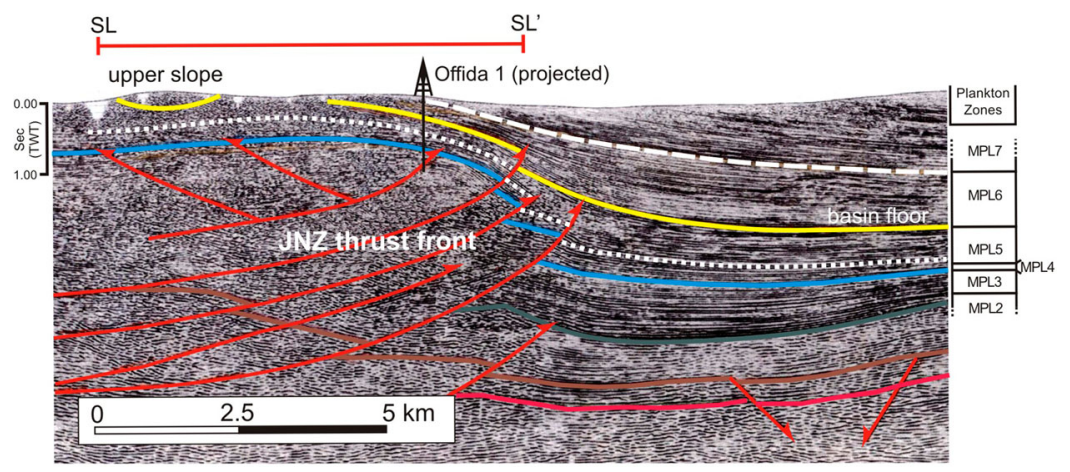

Figure 3. Interpreted, southwest-northeast-oriented seismic line (FTR-19-81) across the Castignano and Offida systems (for location of this seismic line see the geological map). Note the large-scale, eastward prograding clinoforms of the early Pleistocene slope system (courtesy of Ministero dello Sviluppo Economico UNMIG and Società Geologica Italiana Assomineraria, http://unmig.sviluppoeconomico.gov.it/videpi/).

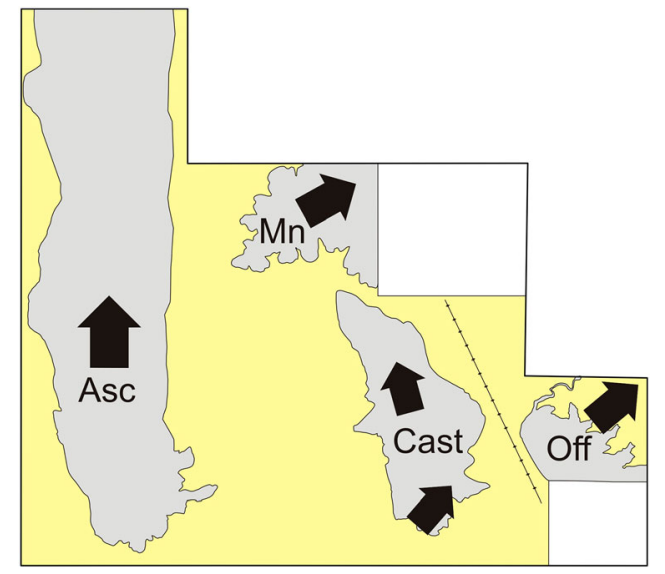

Figure 4. Simplified geologic map of the Gelasian slope turbidite systems (in gray) and enclosing hemipelagic mudstones (in yellow) exposed in the study area. Arrows mark the dominant paleo-flow directions. 'Asc' = Monte Ascensione; 'Cast' = Castignano; 'Off' = Offida; 'Mn' = Montedinove. 
level of exposure, it consists of a south to north elongated body that is approximately $2.5-3 \mathrm{~km}$ wide and can be mapped in a down-dip direction over a distance exceeding $12 \mathrm{~km}$. Internally, the sedimentary succession is organized into a composite fining-upward profile implying a punctuated waning of sediment supply prior to eventual abandonment. On average, the strata strike between $\mathrm{N} 110^{\circ}$ and $\mathrm{N} 140^{\circ}$ and $\operatorname{dip} 10-20^{\circ}$ to the northeast as part of a regional monocline. At Monte Ascensione, in the southernmost portion of the study area, the sedimentary succession consists of laterally amalgamated conglomerate-rich channel-fills interbedded with muddy masstransport complexes and grading into leveed, sand-rich channel-fills to the north (Rotella area). Further north, between the Tesino River and Montelparo, sediments of this turbidite system consist of sand-rich frontal splays and leveed channel-fills, suggesting the existence of a south to north, down-dip transition from coarse proximal (near to source) to fine distal (distant from source) turbiditic facies. This facies-defined proximal-to-distal trend of the system is further supported by paleo-flow directions which indicate an average northerly transport throughout the entire outcrop belt.

\subsection{Castignano system}

Lying above a major basal incision surface, strata of the Castignano system crop out over an area of approximately $25 \mathrm{~km}^{2}$ that extends from Montecalvo in the south, where their eroded headward end projects into the air, to the Tesino River in the north, where the turbidite succession disappears into the subsurface (Di Celma et al., 2013). The Castignano turbidite system traverses across the central portion of the study area in a south to north direction and occurs as an elongated sedimentary body that is about $2-3 \mathrm{~km}$ wide, at least $5.5 \mathrm{~km}$ long and has a maximum total thickness of $270 \mathrm{~m}$. The overall stratigraphy of the Castignano system comprises a heterogeneous succession of conglomerates, sandstones, thinly bedded sandstone and mudstone heterolithics, and pebbly mudstones, which are organized into a composite upward fining trend. Extensive field measurements have demonstrated that paleo-flow indicators from this system all record a dominant sediment transport towards the north, roughly similar to that recorded in the Monte Ascensione system. Only the most southerly exposures of the (Montecalvo area) do not follow this trend and are dominated by a northeasterly directed paleo-flow.

\subsection{Offida system}

Strata of the Offida system cover an area of approximately $4 \mathrm{~km}^{2}$ at the south-eastern end of the study area (Di Celma, 2011). This system, which is, about $3 \mathrm{~km}$ in width has a cyclical appearance consisting of channel-fill conglomerate sand laterally adjacent levee-overbank heterolithics alternating with mud-rich mass-transport deposits. The dominant paleotransport direction is toward the northeast, approximately perpendicular to those recorded in the older Monte Ascensione and Castignano systems.

\subsection{Montedinove system}

The studied portion of this system, covering an area of approximately $4 \mathrm{~km}^{2}$, is exposed in the northern sector of the study area between the villages of Montedinove and Montalto delle Marche. These turbidite sediments include a succession of stacked conglomeratic and sandstone channel-fill deposits with laterally adjacent and vertically alternating finer-grained overbank deposits. Based on unpublished biostratigraphic data from the authors, sediments of the Montedinove system are broadly coeval with those of the Offida system. The paleocurrent data for this 


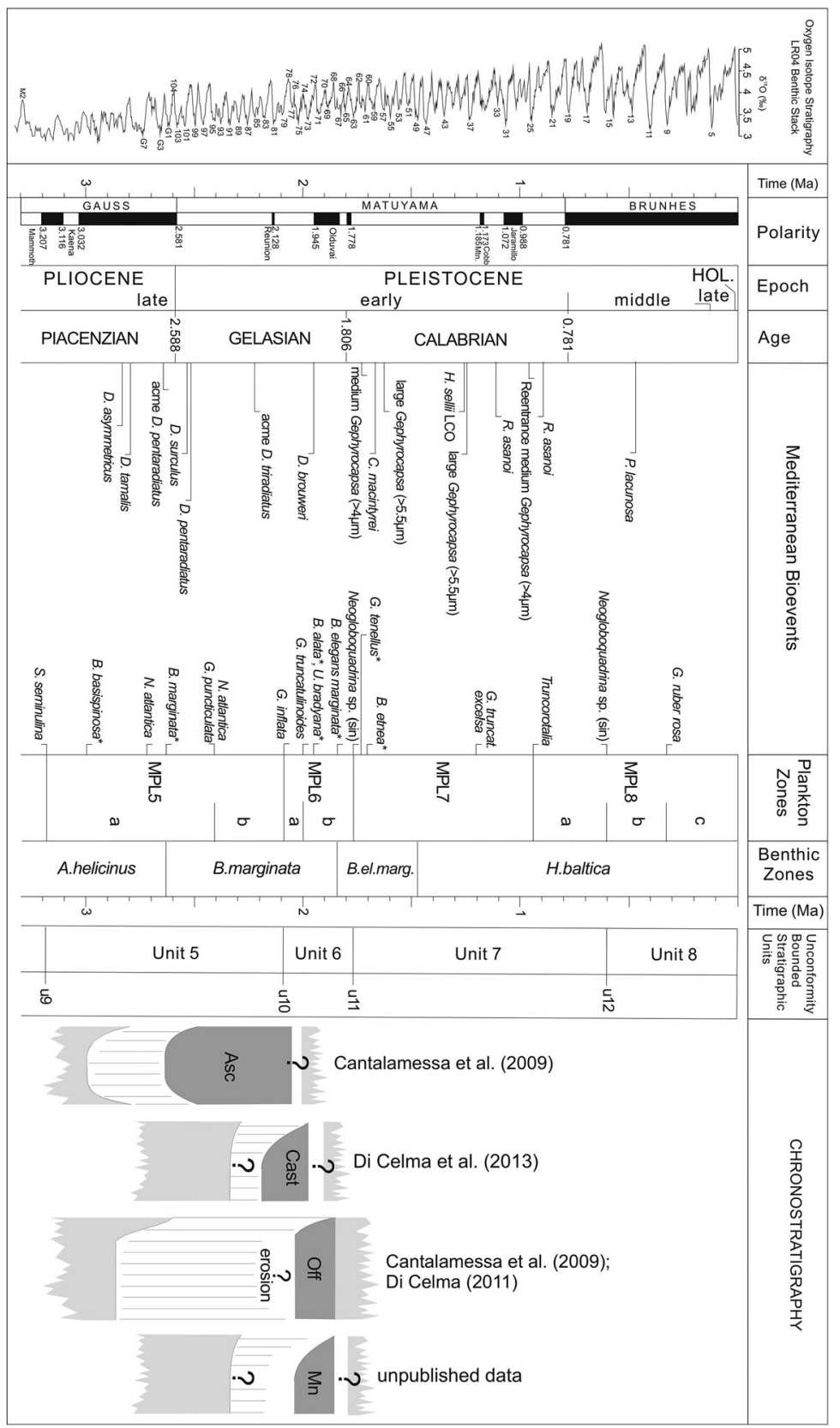

Figure 5. Pliocene-Pleistocene biostratigraphic scheme showing the most significant bioevents of the Mediterranean region. The oxygen isotope curve is from Lisiecki and Raymo (2005). Age of magnetic reversals, stage boundaries, and micropaleontological datum events are based on ATNTS2004 (Lourens, Hilgen, Shackleton, Laskar, \& Wilson, 2004). Age estimation of selected regional bioevents (*) from Pasini and Colalongo (1994), and Patacca and Scandone (2001) and references therein. Benthic Zones after Colalongo and Sartoni (1979). 'Asc' = Monte Ascensione; 'Cast'= Castignano; 'Off' = Offida; 'Mn' = Montedinove. 
system indicate a northeasterly paleo-flow direction, which is the same general direction described earlier for the Offida system.

\section{Depositional model}

The four turbidite-dominated systems exposed in the study area represent long-lived pathways for transport and deposition of coarse-grained clastics within an east-facing, fold and thrust belt-controlled submarine slope. A comprehensive analysis of the outcrop-derived data set in context with the proposed topographically complex character of the slope enables the development of a twophase conceptual model for evolution of the morphology of the continental slope and the downslope sediment transport as the basin progressively filled.

Phase 1: The early to middle Gelasian is characterized by deposition of the Monte Ascensione and Castignano turbidite systems on the western flank of the intraslope anticline. Their courses and paleocurrent directions indicate that the slope configuration had a direct impact on the sediment dispersal pattern, and suggest that although the primary source for sediment was to the west, in the uplifted Apennine orogenic belt, the sediment gravity flows were then redirected to the north (i.e. parallel to the north-south-trending strike of the east-facing slope) by the sea-floor expression of an intraslope, thrust-related anticline (Figure 6(a)). These types of connected and

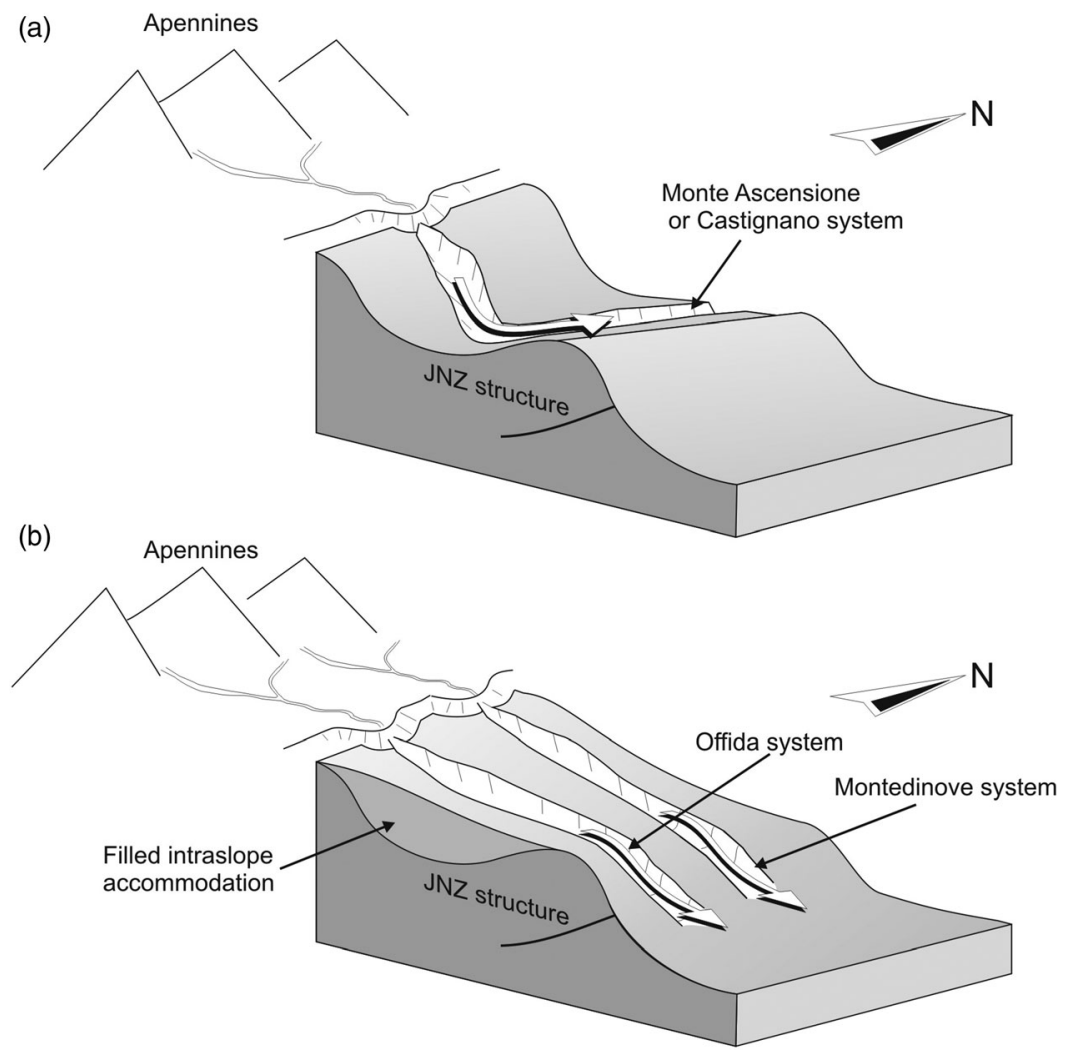

Figure 6. Depositional model for the Gelasian evolution of the study area from an east-facing, complex submarine slope with a pronounced thrust-related step (a) to a smoother, healed sea-floor slope (b). See text for descriptions of the two evolutionary phases. 
variably tortuous flow paths, guided by, but not blocked by, structurally induced bounding ridges are termed a connected tortuous corridor by Smith (2004).

Phase 2: The late Gelasian is represented by the deposition of the youngest parts of the Montedinove and Offida systems. Unlike the earlier depositional systems, these systems cut through the hangingwall anticline above the thrust (Figure 6(b)), probably reflecting the filling up of the intraslope accommodation space on the western flank of the JNZ structure during a period of relative tectonic quiescence. This process of fill and blanketing of a topographic depression on an earlier topographically complex slope resulted in a smooth, healed slope (sensu Smith, 2004) in which two distinct point sources fed canyon-confined channel-levee systems that facilitated northeastward bypass of coarse-grained sediment.

\section{Conclusions}

During the Gelasian, the study area within southern Marche was an upper slope setting at the western, proximal side of the foreland basin system associated with the central Apennine foldthrust belt. The comparison of paleotransport directions and proximal to distal map facies trends of the four turbidite systems exposed in the area helps to determine the controls on a sediment dispersal pattern and reveal a progressive change in slope morphology. Map facies trends and paleocurrent indicators from the Monte Ascensione and Castignano systems converge to indicate that during their deposition the slope had a thrust-related stepped morphology with the sediment-transport path controlled by a margin-parallel anticline. The large-volume turbidity currents entering the slope from the west were diverted northward by this structure and, before being redistributed into the deeper reaches of the adjacent basin, they were forced to travel approximately parallel to the east-facing slope for significant distances, possibly through connected tortuous corridors. Through time, as tortuous corridors were filled, the stepped slope evolved into a smoother, healed slope traversed by dip-oriented, through-going erosional fairways (Montedinove and Offida systems) cutting through the crest of the underlying anticline. The transition from a stepped slope to a smoother, more graded slope suggests that, during the latter part of the Gelasian, erosion and sedimentation largely outpaced structural deformation within the study area.

\section{Software}

The geological map and associated geological sections were compiled by scanning handdrafts as TIF files, and then digitizing the linework using Corel Draw X3.

\section{Acknowledgements}

The authors wish to thank the Posizione di Funzione Informazioni Territorio-Ambiente e Piano Paesaggistico of the Marche Region (http://www.ambiente.marche.it/) for providing the topographic data used for the geological map. Critical reviews by Ivan Marini, Pierparide Gramigna, and Chris Orton, plus editorial comments of Associate Editor Claudio Riccomini and English revision by John P. Kavanagh improved the manuscript. The authors are also very grateful to Stefano Cicora and Pietro Paolo Pierantoni for their help during the fieldwork.

\section{Funding}

Funding for this research was provided by the affiliates of the Reservoir Characterization Project (Shell and Total), who are acknowledged for financial support during the 2011, 2012 and 2013 fieldwork. 


\section{References}

Argnani, A., \& Ricci Lucchi, F. (2001). Tertiary siliciclastic turbidite systems of the northern Apennines. In I. P. Martini \& G. B. Vai (Eds.), Anatomy of an orogen: The Apennines and adjacent Mediterranean basins (pp. 327-350). Amsterdam: Kluwer Academic.

Artoni, A. (2013). The Pliocene-Pleistocene stratigraphic and tectonic evolution of the Central sector of the Western Periadriatic Basin of Italy. Marine and Petroleum Geology, 42, 82-106.

Baas, J. H. (2000). EZ-ROSE: A computer program for equal-area circular histograms and statistical analysis of two-dimensional vectorial data. Computers \& Geosciences, 26, 153-166.

Bigi, S., Conti, A., Casero, P., Ruggiero, L., Recanati, R., \& Lipparini, L. (2013). Geological model of the central Periadriatic basin (Apennines, Italy). Marine and Petroleum Geology, 42, 107-121.

Bouma, A. H. (1962). Sedimentology of some flysch deposits. A graphic approach to facies interpretation. Amsterdam: Elsevier, pp. 1-168.

Bourget, J., Zaragosi, S., Ellouz-Zimmermann, N., Mouchot, N., Garlan, T., Schneider, J.-L., ... Lallemant, S. (2011). Turbidite system architecture and sedimentary processes along topographically complex slopes: The Makran convergent margin. Sedimentology, 58, 376-406.

Cantalamessa, G., \& Di Celma, C. (2004). Sequence response to syndepositional regional uplift: Insights from high-resolution sequence stratigraphy of late Early Pleistocene strata, Periadriatic Basin, central Italy. Sedimentary Geology, 164, 283-309.

Cantalamessa, G., Di Celma, C., Potetti, M., Lori, P., Didaskalou, P., Albianelli, A., \& Napoleone, G. (2009). Climatic control on deposition of upper Pliocene deep-water gravity-driven strata in the Apennines foredeep (central Italy): Correlations to the marine oxygen sea isotope record. In B. Kneller, O. J. Martinsen, \& B. McCaffrey (Eds.), External controls on deep water depositional systems: Climate, sea-level, and sediment flux (Vol. 92, pp. 247-259). Tulsa: SEPM Special Publication.

Chiang, C.-S., \& Yu, H.-S. (2006). Morphotectonics and incision of the Kaoping submarine canyon, SW Taiwan orogenic wedge. Geomorphology, 80, 199-213.

Clark, I. R., \& Cartwright, J. A. (2009). Interactions between submarine channel systems and deformation in deepwater fold belts: Examples from the Levant Basin, Eastern Mediterranean sea. Marine and Petroleum Geology, 26, 1465-1482.

Colalongo, M. L., \& Sartoni, S. (1979). Schema biostratigrafico per il Pliocene e il basso Pleistocene in Italia. Nuovi contributi alla realizzazione della Carta Neotettonica d'Italia, 251, 645-654.

Cronin, B. T. (1995). Structurally-controlled deep sea channel courses: Examples from the Miocene of southeast Spain and the Alboran Sea, southwest Mediterranean. In A. J. Hartley \& D. J. Prosser (Eds.), Characterization of deep marine clastic systems (Vol. 94, pp. 115-135), London: Geological Society (Special Publication).

Dalla Valle, G., Gamberi, F., Trincardi, F., Baglioni, L., Errera, A., \& Rocchini, P. (2013). Contrasting slope channel styles on a prograding mud-prone margin. Marine and Petroleum Geology, 41, 72-82.

Di Celma, C. (2011). Sedimentology, architecture, and depositional evolution of a coarse-grained submarine canyon fill from the Gelasian (early Pleistocene) of the Peri-Adriatic basin, Offida, central Italy. Sedimentary Geology, 238, 233-253.

Di Celma, C., \& Cantalamessa, G. (2012). Off-shelf sedimentary record of recurring global sea-level changes during the Plio-Pleistocene: Evidence from the cyclic fills of exhumed slope systems in central Italy. Journal of the Geological Society, London, 169, 643-646.

Di Celma, C., Cantalamessa, G., \& Didaskalou, P. (2013). Stratigraphic organization and predictability of mixed coarse-grained and fine-grained successions in an upper slope Pleistocene turbidite system of the Peri-Adriatic basin. Sedimentology, 60, 763-799.

Di Celma, C., Cantalamessa, G., Didaskalou, P., \& Lori, P. (2010). Sedimentology, architecture, and sequence stratigraphy of coarse-grained, submarine canyon fills from the Pleistocene (GelasianCalabrian) of the Peri-Adriatic basin, central Italy. Marine and Petroleum Geology, 27, 1340-1365.

Di Celma, C., Teloni, R., \& Rustichelli, A. (2014). Large-scale stratigraphic architecture and sequence analysis of an early Pleistocene submarine canyon fill, Monte Ascensione succession (Peri-Adriatic central Italy). International Journal of Earth Sciences (Geol. Rundsch.), 103, 843-875.

Doglioni, C. (1991). A proposal for the kinematic modelling of W-dipping subductions-possible applications to the Tyrrhenian-Appennines system. Terra Nova, 3, 423-434.

Hodgson, D. M., \& Haughton, P. D. W. (2004). Impact of syndepositional faulting on gravity current behaviour and deep-water stratigraphy: Tabernas-Sorbas basin, SE Spain. In S. A. Lomas \& P. Joseph (Eds.), Confined turbidite systems (Vol. 222, pp. 135-158). London: Geological Society (Special Publications).

Kukowski, N., Schillhorn, T., Huhn, K., von Rad, U., Husen, S., \& Flueh, E. R. (2001). Morphotectonics and mechanics of the central Makran accretionary wedge off Pakistan. Marine Geology, 173, 1-19. 
Lisiecki, L. E., \& Raymo, M. E. (2005). A Pliocene-Pleistocene stack of 57 globally distributed benthic $\delta^{18} \mathrm{O}$ records. Paleoceanography, 20, PA1003. doi:10.1029/2005PA001153.

Lourens, L., Hilgen, F., Shackleton, N. J., Laskar, J., \& Wilson, D. (2004). The Neogene period. In F. M. Gradstein, J. G. Ogg, \& A. G. Smith (Eds.), A geological time scale (pp. 409-440). Cambridge: Cambridge University Press.

Lowe, D. R. (1982). Sediment gravity flows: II. Depositional models with special reference to the deposits of high-density turbidity currents. Journal of Sedimentary Petrology, 52, 279-297.

Malinverno, A., \& Ryan, W. B. F. (1986). Extension of the Tyrrhenian Sea and shortening in the Apennines as a result of arc migration driven by sinking of the lithosphere. Tectonics, 5, 227-245.

Mayall, M., Lonergan, L., Bowman, A., James, S., Mills, K., Primmer, T., ... Skeene, R. (2010). The response of turbidite slope channels to growth-induced seabed topography. American Association of Petroleum Geologists Bulletin, 94, 1011-1030.

Mountjoy, J. J., Barnes, P. M., \& Pettinga, J. R. (2006). Morphostructure and evolution of submarine canyons across an active margin: Cook Strait sector of the Hikurangi Margin, New Zealand. Marine Geology, $260,45-68$.

Ori, G. G., Serafini, G., Visentin, C., Ricci Lucchi, F., Casnedi, R., Colalongo, M. L., \& Mosna, S. (1991). The Plio-Pleistocene Adriatic foredeep (Marche and Abruzzo, Italy) - an integrated approach to surface and subsurface geology. Adriatic foredeep field guide for the third conference of European Association of Petroleum Geology, Florence, Italy (85 p).

Pasini, G., \& Colalongo, M. L. (1994). Proposal for the erection of the Santernian/Emilian boundary-stratotype (lower Pleistocene) and new data on the Pliocene/Pleistocene boundary stratotype. Bollettino della Società Paleontologica Italiana, 33, 101-120.

Patacca, E., \& Scandone, P. (2001). Late thrust propagation and sedimentary response in the thrust belt-foredeep system of the Southern Apennines (Pliocene-Pleistocene). In I. P. Martini \& G. B. Vai (Eds.), Anatomy of an orogen: The Apennines and adjacent Mediterranean basins (pp. 401-440). Amsterdam: Kluwer Academic.

Ricci Lucchi, F. (1986). The Oligocene to recent foreland basins of northern Apennines. In P. A. Allen \& P. Homewood (Eds.), Foreland basins (Vol. 8, pp. 105-139). Oxford: International Association Sedimentologists (Special Publication).

Smith, R. (2004). Silled sub-basins to connected tortuous corridors: Sediment distribution systems on topographically complex sub-aqueous slopes. In S. A. Lomas \& P. Joseph (Eds.), Confined turbidite systems (Vol. 222, pp. 23-43). London: Geological Society (Special Publications).

Tinterri, R., \& Lipparini, L. (2013). Seismo-stratigraphic study of the Plio-Pleistocene foredeep deposits of the Central Adriatic Sea (Italy): Geometry and characteristics of deep-water channels and sediment waves. Marine and Petroleum Geology, 42, 30-49.

Tozer, R. S. J., Butler, R. W. H., Chiappini, M., Corrado, S., Mazzoli, S., \& Speranza, F. (2006). Testing thrust tectonic models at mountain fronts: Where has the displacement gone? Journal of the Geological Society, London, 163, 1-14. 